\title{
On the bibasic arseniate of ammonia and magnesia
}

\section{Levol}

To cite this article: M. Levol (1846) On the bibasic arseniate of ammonia and magnesia, Philosophical Magazine Series 3, 29:193, 243-243, DOI: 10.1080/14786444608645623

To link to this article: http://dx.doi.org/10.1080/14786444608645623

曲 Published online: 30 Apr 2009.

Submit your article to this journal ๘

Џ Article views: 3

Q View related articles $\sqsubset$ 


\section{ON THE BIBASIC ARSENIATE OF AMMONIA AND MAGNESIA. BY M. LEVOL.}

The author observes, that, notwithstanding the striking analogies presented by arsenical and phosphoric compounds, it does not appear to have been ascertained whether an arsenical compound exists, corresponding to the most important of the ammoniaco-magnesian double phosphates, or that which occurs among certain products of animul organization, and which is so frequently employed in chemical analyses, on account of its insolubility, to determine the quantity of phosphoric acid.

The author thought it would be interesting to determine if it were possible to produce an arseniate analogous to this phosphate, and to apply it, on account of its insolubility, to ascertain the quantity of arsenic acid; and he found, in fact, that such a salt exists, and that it resembles in every respect the bibasic phosphate of the same bases, and its formula is similar to that which Berzelius assigns to the phosphate $2 \mathrm{NH}^{3}, 2 \mathrm{MgO}, \mathrm{AsO}^{5}+10 \mathrm{HO}$.

This salt is obtained like the corresponding phosphate, that is to say by pouring a soluble double ammoniaco-magnesian salt into a solution of arsenic acid, after having rendered it ammoniacal; like the phosphate, it does not immediately appear, but only after the lapse of a few seconds, unless it be agitated; it deposits in the same way in the form of very small crystals on the sides of the vessel; its insolubility may also be compared to that of the phosphate : one part of arsenic acid, diluted with 56818 parts of ammoniated water, was rendered sensible soon after the addition of a few drops of a concentrated solution of ammoniaco-magnesian sulphate; and the author is of opinion that it would be difficult to mention two salts more exactly comparable each to the other, than the phosphate and arseniate under consideration.

The new salt was applied in a very difficult case of chemical analysis, that of the quantitative separation of arsenious and arsenic acids, the former not yielding a double insoluble salt with ammonia and magnesia. When the precipitate is collected, it is to be dried and calcined to redness, taking care that it is not exposed to any reducing influence; there remains $2 \mathrm{MgO}, \mathrm{AsO}^{5}=55 \cdot 74$ of 100 of the new salt, which represent 41.02 of arsenic acid. The author suggests that the ammoniaco-magnesian double salts might be employed as remedies in cases of poisoning by arsenic acid.-Ann. de Ch. et de Phys., Août 1846.

\section{EXAMINATION OF a FOSSIL RESIN FOUND NEAR EU (SEINE- INFERIEURE). BY MM. IASSAIGNE AND CHEVALLIER.}

This substance may be mistaken for amber, which it resembles in its yellowish colour, transparency, fusibility and combustibility. One specimen of a pale yellow colour, was of sp. gr. 1.094; the other, which was reddish-yellow, had a sp. gr. of 1 .

The first of these specimens was reduced to fine powder, and ma- 